\title{
BUDIDAYA IKAN PATIN DI VIETNAM: Suatu Kajian Untuk Pengembangan Budidaya Ikan Patin Indonesia
}

\author{
Nina Meilisza \\ Loka Riset Budidaya Ikan Hias Air Tawar \\ Jl. Perikanan No. 13, Pancoran Mas, Depok 16436 \\ Email: sirunina@yahoo.com
}

\begin{abstract}
ABSTRAK
Budidaya ikan patin telah lama dilakukan di Indonesia dan menjadi salah satu komoditas penting dalam dunia perikanan. Ikan patin tidak hanya po puler sebagai ikan konsumsi namun juga disukai sebagai ikan hias saat masih kecil karena bentuk, warna dan pergerakannya yang indah. Perkembangan budidaya ikan patin di Indonesia tidak secepat yang terjadi di Vietnam. Sebagai negara yang memiliki luas lahan perairan umum dan potensi sumberdaya manusia yang cukup besar, Indonesia hanya mampu menempati posisi kelima dalam produksi patin dunia. Produksi ikan patin Vietnam mencapai jumlah 1,2 juta ton di tahun 2007, sedangkan Indonesia hanya mampu memproduksi sekitar 36.250 ton. Perbandingan ini sangat signifikan dan menjadi pertanyaan besar apa saja yang telah dilakukan oleh pelaku perikanan kita. Budidaya ikan patin telah memberikan kontribusi besar dalam perekonomian Vietnam dan menjadi penggerak roda ekonomi masyarakatnya. Keberhasilan Vietnam perlu dipelajari dan dikaji sebagai acuan dalam mengembangkan budidaya ikan patin di Indonesia.
\end{abstract}

KATAKUNCl: ikan patin, budidaya ikan patin di Vietnam, budidaya ikan patin di Indonesia

\section{PENDAHULUAN}

Ikan patin telah dikenal di Indonesia sejak tahun 1970an dan kemudian berkembang hingga saat ini. Selain populer sebagai ikan konsumsi, ikan patin juga terkenal sebagai ikan hias utamanya yang berukuran kecil, karena warna dan caranya berenang yang membuat konsumen menyukainya. Menurut Khairuman \& Sudenda (2002), di Indonesia sedikitnya terdapat dua jenis ikan patin yang populer dan banyak dibudidayakan, yaitu patin siam dan patin lokal. Spesies patin siam yang dimaksud adalah
Pangasianodon hypophthalmus, sedangkan patin lokal adalah Pangasius djambal Bleeker.

Produksi ikan patin di Indonesia tidak sebesar ikan mas dan nila meskipun produksi ikan patin di Indonesia meningkat secara signifikan sejak tahun 2004 dan diperkirakan akan terus meningkat hingga tahun 2009 (Gambar 1). Peningkatan ini tidak serta merta menjadi gambaran keberhasilan produksi patin di Indonesia karena pada kenyataannya produksi ini hanya berkisar 30.00050.000 ton per tahun dan secara kuantitatif tidak akan mampu memenuhi pasar domestik apalagi ekspor.

Potensi pengembangan budidaya ikan patin di Indonesia sangat besar, mengingat spesies ini mudah dibudidayakan baik dalam kolam maupun karamba. Selain itu, teknologi budidaya ikan patin telah dikuasai mulai dari proses pematangan gonad induk, penetasan telur, pemeliharaan larva, pendederan hingga pembesaran. Dilihat dari luas lahan di Indonesia, menurut Dahuri (2004) ada sekitar 54 juta hektar perairan umum (sungai, waduk, danau, rawa) yang dapat dimanfaatkan dalam budidaya perikanan.

Besarnya potensi budidaya patin di Indonesia tidak mampu menjadikannya produsen patin terbesar dunia.

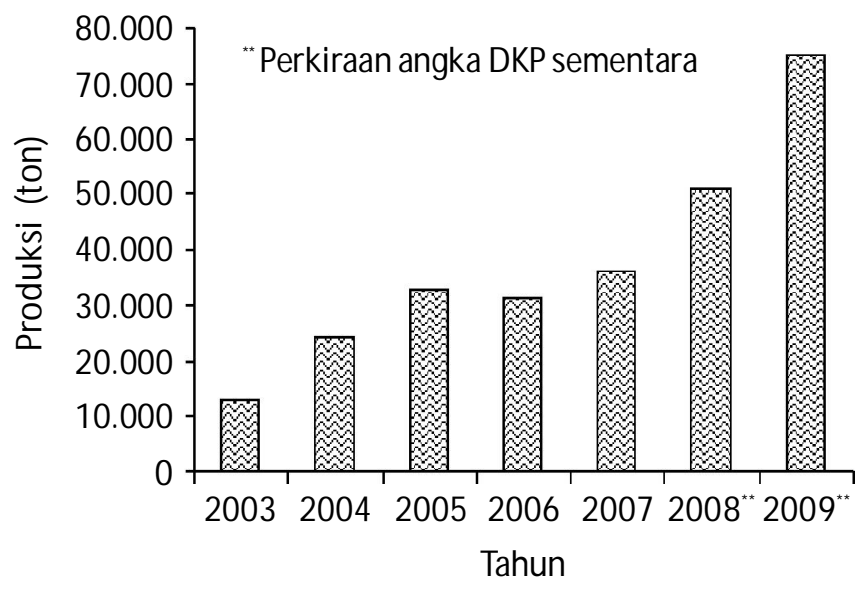

Sumber: Departemen Kelautan dan Perikanan (2009)

Gambar 1. Produksi budidaya ikan patin di Indonesia tahun 2003-2009 
Produksi budidaya patin tertinggi justru dihasilkan oleh Vietnam sebesar 1,2 juta ton pada tahun 2007 dan diperkirakan meningkat menjadi 2 juta ton di tahun 2008 (Anonim, 2008; Phuong et al., 2008; Silva, 2008). Keberhasilan Vietnam ini dapat menjadi acuan sebagai bahan pelajaran bagi pelaku usaha perikanan budidaya patin di Indonesia dalam meningkatkan kuantitas maupun kualitas produksinya.

\section{GAMBARAN UMUM PRODUKSI BUDIDAYA IKAN PATIN DI VIETNAM}

Vietnam adalah salah satu negara di Asia yang mengalami perkembangan pesat dibidang budidaya ikan. Secara geografis, Vietnam didukung oleh sebuah perairan yang cukup besar yang melintasi negara ini berupa sungai besar yang bernama Mekong. Sungai Mekong memiliki banyak percabangan anak sungai dan kanal yang melintasi beberapa negara di antaranya China, Kamboja, Vietnam, Thailand, dan Laos. Di Vietnam, sedimentasi aliran air dari Sungai Mekong membentuk suatu daratan yang dikelilingi perairan disebut dengan nama M ekong delta.

Mekong delta terletak di bagian utara Vietnam yang menutupi 12\%dari total area negara tersebut. Delta ini memiliki lebih dari 4 juta ha lahan yang terisi oleh badan air sekitar 954.350 ha. Dari total badan air yang ada, luas area badan air tawar berjumlah sekitar 641.350 ha atau 67,2\%dari total permukaan air sedangkan sisanya adalah air payau. Lebih dari 70\%dari total produksi budidaya perikanan terdapat di area ini (Wilder \& Phuong, 2002).

Pada tahun 2003, Mekong delta telah menghasilkan produksi budidaya perikanan sebanyak 740.369 ton atau $66,9 \%$ dari produksi total budidaya perikanan Vietnam (1.105.300 ton di tahun 2003 meningkat 14,5\%dibanding tahun 2002) (M onti et al., 2003). Spesies ikan yang umum dibudidayakan di perairan Mekong delta adalah ikan mas, silver barb, dan tilapia sebagai konsumsi lokal sedangkan patin sebagai komoditas ekspor (Wilder \& Phuong, 2002; Phillips, 2002 dalam Monti et al., 2003).

Ikan patin di Vietnam merupakan spesies yang paling berkembang dalam kegiatan budidaya serta merupakan hasil introduksi dan diperkenalkan dari negara Thailand. Budidaya ikan patin di Vietnam telah menghasilkan prestasi dan kontribusi yang sangat besar dalam perekonomian negara tersebut karena telah berhasil memproduksi sekitar 1,2 juta ton pada tahun 2007, dan diprediksi akan meningkat menjadi 2 juta ton pada tahun 2008 (Anonim, 2008; Phuong et al., 2008; Silva, 2008). Produksi ini menempati Vietnam sebagai produsen ikan patin terbesar nomor 1 di dunia dengan spesies utama Pangasianodon hypophthalmus.
Perkembangan pesat budidaya ikan patin di Vietnam diawali sekitar tahun 1999 di mana Departemen Perikanan Vietnam mencatat 83 hatcheri (tempat pembenihan ikan) dan sekitar 200 stasiun pendederan ikan tradisional terdapat di Mekong delta. Hal ini adalah dampak dari berhasilnya penerapan reproduksi artifisial pangasius yang menurunkan ketergantungan pasokan larva dan fingerling dari alam. Di tahun 2000, lebih dari 32 hatcheri dapat memproduksi lebih dari 15 juta post larva, yang meningkat cepat jika dibandingkan tahun sebelumnya yaitu tahun 1999 yang hanya menghasilkan sekitar 2 juta post larva (Wilder \& Phuong, 2002).

Keberhasilan reproduksi ikan patin dihasilkan dari dua jenis spesies yaitu 'tra' Pangasianodon hypophthalmus dan 'basa' Pangasius bocourti. Keberhasilan produksi ini menyebabkan budidaya ikan patin ini meningkat dengan signifikan secara bertahap dalam sistem budidaya karamba dan kolam. Dari kedua spesies tersebut, P. hypophthalmus merupakan spesies yang terbanyak dibudidayakan dengan peningkatan area dari 1.290 ha di tahun 1997 menjadi 2.720 ha di tahun 2002 (17\%per tahun) (Monti et al., 2003).

\section{TEKNIK BUDIDAYA IKAN PATIN DI VIETNAM}

Teknik budidaya ikan patin di Vietnam tidak berbeda jauh seperti di Indonesia. Selama melakukan perjalanan di Vietnam, penulis mendatangi beberapa lokasi budidaya mulai dari tahap pembenihan, pendederan, pembesaran, hingga pemroresan di salah satu kota penting dalam aktivitas budidaya ikan patin yaitu Can Tho.

Di Vietnam, budidaya ikan patin dilakukan secara ekstensif, semi intensif dan intensif. Cara ekstensif dilakukan dengan padat penebaran ikan yang rendah dengan total produksi yang sedikit dan biaya yang rendah sehingga banyak dilakukan dalam skala rumah tangga atau oleh pembudidaya kecil. Budidaya semi intensif dan intensif dilakukan oleh suatu farm atau perusahaan. Budidaya yang dilakukan oleh farm atau perusahaan melibatkan banyak pembudidaya-pembudidaya ikan yang diberi wewenang mengelola beberapa kolam dan karamba. Pada awal perkembangan budidaya, P. boucorti mendominasi produksi dibandingkan P. hypophthalmus, namun kurang dari 10 tahun terakhir P. hypophthalmus lebih banyak bahkan dominan dalam pemudidayaan. Siklus produksi P. hypophthalmus di Vietnam terlihat pada Gambar 2.

Budidaya ini terkonsentrasi di beberapa Provinsi seperti An Giang, Dong Thap, Vinh Long, dan Can Tho (Monti et al., 2009). Provinsi Dong Thap terkenal dengan budidaya patin P. hypophthalmus dan berkontribusi sebesar 37,5\%dari total produksi di Vietnam (Hung et al., 2008). 


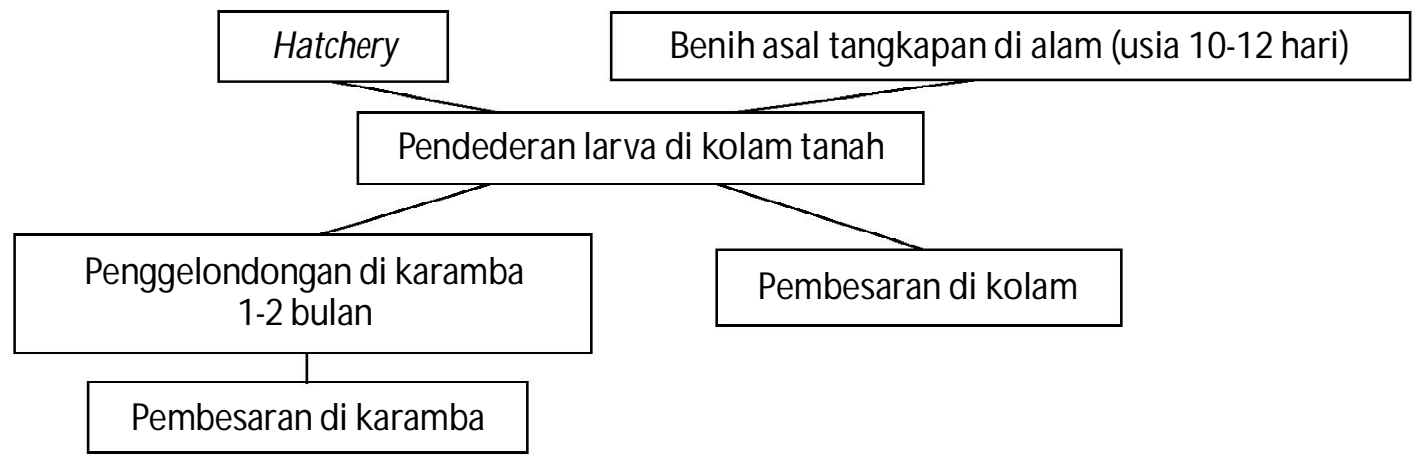

Sumber: Hung \& Cacot (2000) dalam Trong et al. (2002)

Gambar 2. Siklus produksi P. hypophthalmus di Vietnam

Perusahaan-perusahaan besar yang terlibat disini menerapkan sistem budidaya terpadu (integrated farming system) dengan sistem budidaya dari hulu ke hilir. Salah satu yang terbesar adalah CASEAMEX company. Hasil kunjungan (survai) penulis bulan Desember 2008 ke perusahaan ini menghasilkan informasi yang sangat penting dan bermanfaat untuk pelajaran dan acuan dalam penerapan budidaya ikan patin di Indonesia. Secara umum budidaya dilakukan dengan area atau lokasi yang berbeda disesuaikan stadia ikannya yaitu: area pusat produksi benih (Seed production centre), pembesaran (Grow-out farm), dan pemrosesan hasil panen. Produksi patin di CASEAM EX dapat dijelaskan seperti yang divisualisasikan pada Gambar 3.

\section{Pusat Produksi Benih (Seed Production Centre)}

Pusat produksi benih CASEAMEX berlokasi di Tra on district, Vinh Long province, area ini dibangun sebagai

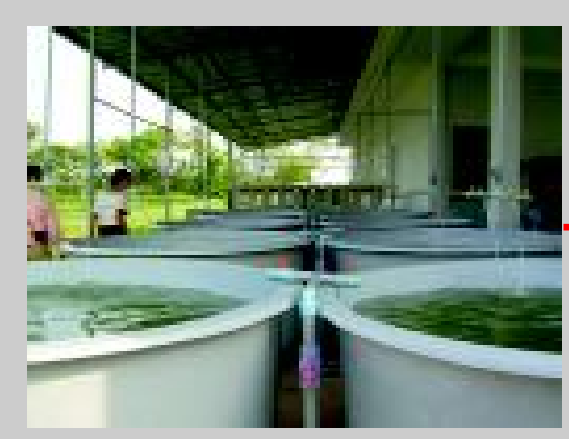

a. Bak persiapan pemijahan induk

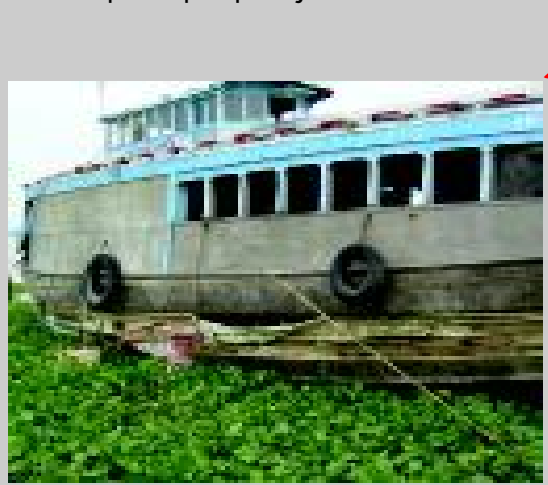

d. Kapal pengangkut benih/fingerlings lubang sirkulasi air pada bagian bawahnya menuju lokasi pembesaran

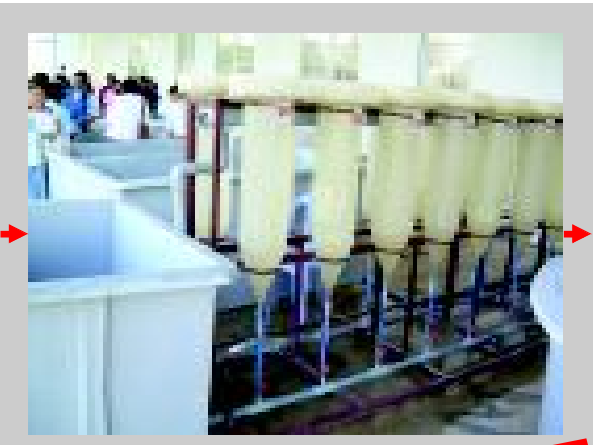

b. Corong penetasan telur

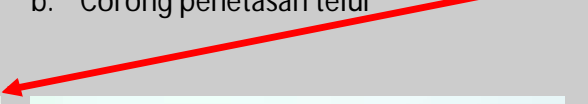

c. Kolam pendederan larva menuju tahap pendederan/fingerlings

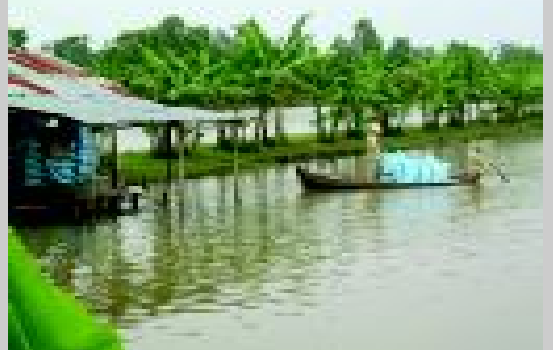

e. Pembesaran dalam kolam

7

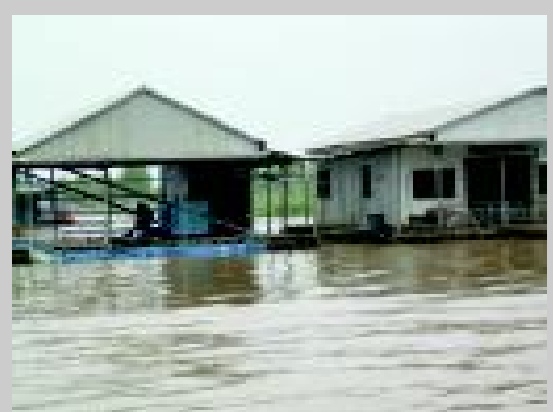

f. Pembesaran dalam karamba

Gambar 3. Siklus produksi budidaya ikan patin dari tahap pemijahan hingga pembesaran $(a, b, c)$ produksi benih (d) alat transportasi ikan $(e, f)$ pembesaran di kolam dan karamba 
tempat transfer teknologi dari fakultas budidaya perairan dan perikanan, Universitas Can Tho, Vietnam. Luas total area saat ini $15 \mathrm{ha}$, dengan area penelitian 1.200 $\mathrm{m}^{2}$. Total area ini digunakan juga untuk kolam calon induk 6 buah masing-masing luas $1.500 \mathrm{~m}^{2}$ (luas total $9.000 \mathrm{~m}^{2}$ ), kolam pengasuhan atau perawatan larva 43 buah dengan total area $86.000 \mathrm{~m}^{2}\left(2.000 \mathrm{~m}^{2}\right.$ per kolam), kolam pasca pemijahan 1 kolam seluas $2.000 \mathrm{~m}^{2}$. Musim pemijahan terjadi pada bulan Februari sampai Oktober. Calon induk berjumlah 50 ton atau $8.300 \mathrm{ikan}$, dengan padat tebar 0,5-1,0 kg per $\mathrm{m}^{2}$.

Pakan induk yang digunakan adalah pelet dengan kandungan protein 32\% Tingkat pemberian pakan sebanyak 1,0\%1,5\%per bobot badan per hari. Kapasitas produksi benih 500 juta ekor per tahun, dimana $50 \%$ benih dijual dan sisanya dipelihara sampai ukuran fingerling sebagai stok (30-60 juta).

\section{Area Pembesaran (Grow-Out Farm)}

Area terdapat diberbagai lokasi berbeda di antaranya Soc Trang, Tra Vinh, Vinh Long, dan Can Tho City. Di Can Tho, total area kolam budidaya seluas 7,5 ha dengan total produksi sekitar 3.800 ton per tahun. Ukuran kolam yang digunakan adalah 7.000-10.000 $\mathrm{m}^{2}$ (70x100x3,5 m dan $80 \times 125 \times 3,5 \mathrm{~m})$.

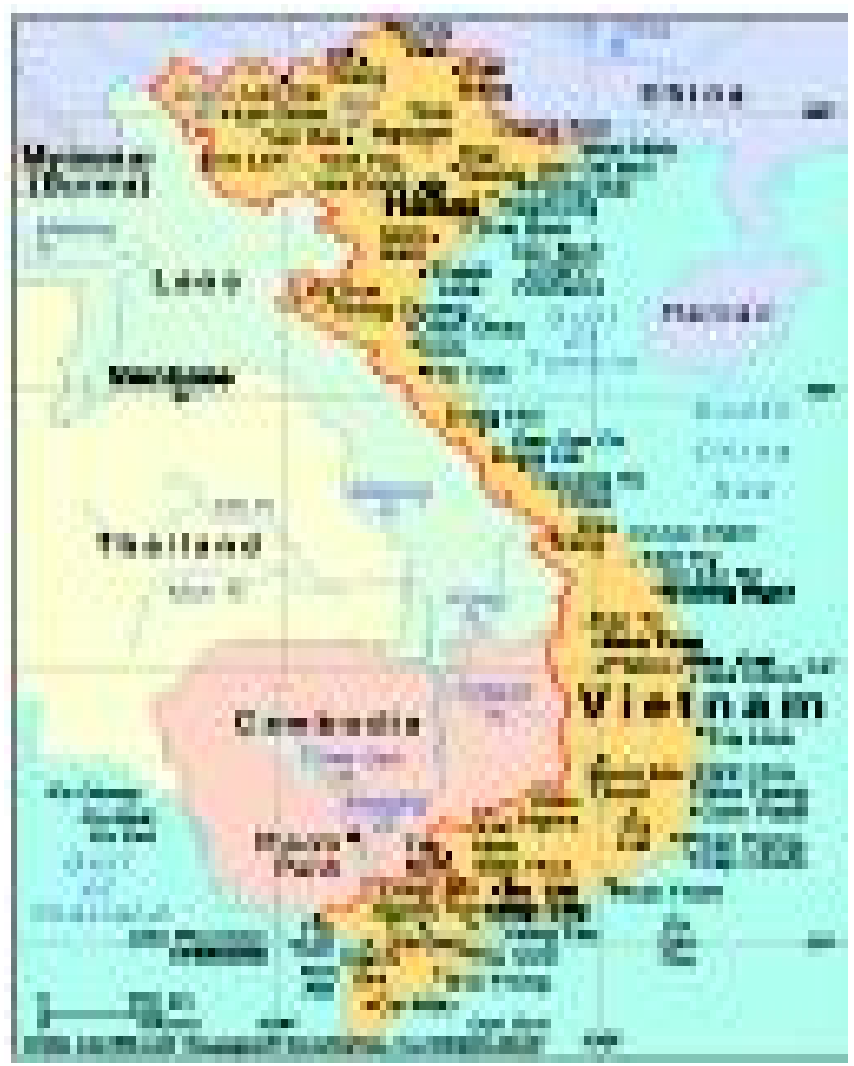

Gambar 4. Peta Vietnam
Area ini beroperasi sepanjang tahun dengan waktu 6-7 bulan untuk 1 kali panen. Padat tebar ikan berkisar 30-35 fingerling $/ \mathrm{m}^{2}$ dengan ukuran fingerling 15-20 g per ikan. Pakannya adalah pelet dengan tingkat pemberian 1,2\%7,0\%per bobot badan per hari menghasilkan FCR 1,5-1,65. Tingkat sintasan berkisar 75\%80\% Produksi hasil panen sekitar 300 ton per ha setiap panen dengan ukuran panen 1,0-1,2 kg per ekor. Kualitas hasil panen bebas residu antibiotik dan lebih dari $90 \%$ berdaging putih.

\section{Area Pemrosesan Hasil Panen}

Hasil produksi patin di Vietnam sebagian besar menjadi komoditas ekspor ke berbagai negara di dunia. Beberapa perusahaan yang telah menerapkan sistem budidaya ikan terpadu (integrated farming system) memproses hasil panennya sendiri. Pemrosesan dilakukan dalam suatu area pabrik pengolahan dan ruang pendinginan (cold storage).

Area pemrosesan hasil panen berada tidak jauh dari lokasi pembesaran dengan tujuan mempermudah transportasi dan mencegah kerusakan ikan. Transportasi dilakukan dengan menggunakan kapal atau perahu yang memuat ikan dalam keadaan hidup. Pada bagian bawah kapal atau perahu dilengkapi dengan lubang-lubang tempat keluar masuknya air yang memuat ikan.

Kapal atau perahu yang telah mendarat di sekitar area pabrik selanjutnya diangkut dan dibawa ke dalam pabrik dengan proses yang higienis. Pengangkutan ikan ke dalam pabrik dilakukan dalam wadah-wadah besar seperti ember besar atau sejenisnya. Seleksi dilakukan menurut ukuran dan kepentingan pembuatan produk olahan.

Untuk satu pabrik pengolahan mampu mengekspor hasil olahan lebih dari 30 ton per hari. Ada sekitar 19 bentuk produk olahan patin yang dihasilkan dari pemrosesan ini yaitu:

1. Patin utuh (whole pangasius)

2. Fillet patin daging putih (pangasius fillets white meat)

3. Fillet dengan kulit (skin on fillet)

4. Fillet daging merah tanpa kulit (skinless, red meat on fillet)

5. Fillet tanpa lemak tanpa kulit (skinless, untrimmed fillet)

6. Daging patin spiral (pangasius medallions, rolls)

7. Daging patin cincin (pangasius rings)

8. Steak patin (pangasius steak)

9. Daging patin batang ukuran jari (pangasius strips and fingers)

10. Daging patin sate (pangasius skewers)

11. Daging patin cacah beku (broken meat) 
12. Daging patin cacah kerat berkulit (skin on slice)

13. Daging patin berkulit dalam potongan porsi (skin on portion cut)

14. Patin utuh tanpa tulang belakang (wholefish collar bone)

15. Patin potongan bebas berkulit (skin on free cut)

16. Patin potongan berkulit ( skin on cut)

17. Patin berkulit dalam potongan porsi (skin on portion cut)

18. Fillet patin dengan tepung roti (pangasius breaded fillet)

19. Nugget patin (re-fried breaded pangasius nuggets)

Pada awalnya negara terbesar tujuan ekspor patin adalah Amerika Serikat, dimana pada tahun 2000 negara ini yang sudah lama menjadi importir berbagai produk perikanan Vietnam menjadi fokus mengimpor patin. Peningkatan nilai ekspor patin ini terlihat dari tahun 1998 sejumlah 272,4 ton kemudian naik menjadi 7718 ton di tahun 2001 (McManama, 2003). Pasar produksi patin Vietnam kemudian berkembang dan telah memenuhi lebih dari 40 negara tujuan ekspor seperti negara-negara Timur Tengah, Eropa, Rusia, Kanada, Australia, Korea, Hongkong, China, Singapore, Malaysia, dan Thailand sebagai fillet beku dan terdapat sekitar 80 produk olahan patin bernilai jual lainnya. Besarnya permintaan ekspor patin negara-negara lain membuat Amerika Serikat bukan lagi importir patin terbesar di Vietnam.

\section{PENGEMBANGAN BUDIDAYA IKAN PATIN DI INDONESIA}

Indonesia sebagai negara yang memiliki banyak sungai, danau, dan rawa, berpotensi besar mengembangkan budidaya patin melebihi Vietnam. Dengan luasnya lahan untuk budidaya tersebut, beberapa Provinsi berpeluang menjadi pusat kegiatan budidaya patin, selain itu ikan patin sangat disukai sebagai ikan konsumsi maupun ikan hias oleh masyarakat.

Indonesia memiliki beberapa sungai besar seperti sungai Musi, Batanghari, Mahakam, Kapuas, serta danaudanau besar seperti Toba, Ranau, Singkarak dan banyak lainnya, tentunya sangat berpeluang menjadi penghasil ikan patin terbesar. Namun kenyataan pada saat ini Indonesia hanya mampu menempati posisi kelima dalam produksi patin dan jika dilihat secara kuantitasnya, jumlah inipun belum mampu memenuhi kebutuhan domestik apalagi ekspor.

Pengembangan ikan patin di Indonesia telah dilaksanakan sejak era tahun 1980 sebagai ikan introduksi dari Thailand. Beberapa tahun belakangan ini lembaga pemerintah di bawah Direktorat Jenderal Budidaya dan
Badan Riset Kelautan dan Perikanan telah mengaplikasikan teknologi budidaya ini hingga ke masyarakat.

Beberapa program yang telah dilakukan di antaranya adalah subsidi benih ke daerah-daerah, pengembangan kolam budidaya, pelatihan budidaya dan pembuatan pakan, dan lain sebagainya. Sudah selayaknya program ini didukung penuh dengan beberapa tindakan lebih lanjut seperti:

- Kebijakan dan dukungan pemerintah dalam rencana strategis budidaya perikanan

- Penanaman modal swasta dalam dan luar negeri, usaha ini dapat dilakukan dengan melakukan kerjasama dengan perusahaan perikanan skala nasional dalam membangun dan mengembangkan area budidaya. Usaha dapat juga dilakukan dengan mengundang investor luar negeri dengan perjanjian keuntungan yang disepakati bersama.

- Perencanaan dan pelaksanaan budidaya ikan patin dengan sistem budidaya terpadu (integrated farming system)

- Pengembangan kawasan atau area budidaya hulu ke hilir melalui pembangunan infrastruktur, pusat produksi benih, kolam atau karamba, dan pabrik pemrosesan

- Perubahan arah pengembangan budidaya kolam dan karamba dengan memanfaatkan sumberdaya air dan daerah pinggir sungai dan danau

- Pemberdayaan masyarakat sekitar sungai dan danau melalui pemberian ketrampilan dan bantuan modal benih serta perlengkapan budidaya. Pemberdayaan ini dapat juga dilakukan dengan menjadikan masyarakat sebagai tenaga kerja

- Pengembangan provinsi berpotensi sungai dan danau

- Pengawasan dan pengendalian stok induk dan benih melalui kontinuitas produksi benih, pemijahan, pengobatan yang tepat dan pemeliharaan kualitas induk

- Pengawasan dan pengendalian untuk kesinambungan produksi melalui pengontrolan jumlah benih, regenerasi induk, manajemen pakan dan lingkungan

- Pengawasan dan pengendalian lingkungan melalui pelaksanaan AM DAL yang konsisten, penataan sistem resirkulasi air, penampungan dan pengelolaan limbah buangan, penggunaan antibiotik yang tepat, pencegahan penyakit dan pengelolaan kualitas air yang baik.

Dengan demikian potensi patin yang ada saat ini dapat ditingkatkan, sehingga dapat dijadikan komoditas yang lebih bernilai. Cara budidaya di Vietnam ini bisa menjadi 
inspirasi untuk Indonesia sebagai penghasil patin yang lebih bermutu. Apalagi spesies patin asal Indonesia terkenal dengan rasanya yang lebih enak.

\section{KESIMPULAN}

1. Budidaya ikan patin di Vietnam secara umum tidak banyak berbeda dengan yang ada di Indonesia, namun berkembang jauh lebih pesat. Perbedaan mendasar dalam budidaya patin di Vietnam adalah penerapan sistem budidaya terpadu dari hulu ke hilir dan dilaksanakan baik secara ekstensif maupun intensif. Investasi swasta dalam hal ini sangat berperan menunjang pertumbuhan dan perkembangan budidaya patin di Vietnam.

2. Peran swasta mampu menyerap lapangan kerja masyarakat serta permodalan bagi para petani kecil di sekitarnya, swasta juga mampu menghasilkan produk olahan lainnya yang memungkinkan diferensiasi dan penyerapan pasar. Keberadaan beberapa perusahaan swasta besar dalam budidaya patin terpadu ini juga mampu memperluas pemasaran ikan hingga ke mancanegara.

3. Dilihat dari luas potensi lahan untuk budidaya patin di Vietnam tidak sebesar Indonesia namun keberadaan Mekong delta sebagai sumberdaya air dan lahan benarbenar dimanfaatkan secara optimal meskipun secara teknis budidaya ikan patin di Vietnam tidak berbeda jauh dengan Indonesia.

4. Kekurangan yang terjadi di Indonesia adalah kurangnya peran swasta dalam budidaya patin, banyaknya sumberdaya alam yang tidak termanfaatkan secara optimal, masih mengandalkan penangkapan di alam, kurangnya bantuan permodalan dan akses pasar serta permasalahan lainnya. Budidaya patin di Vietnam selayaknya menjadi inspirasi untuk per"patin'an di tanah air agar dapat lebih maju di masa depan.

\section{DAFTAR ACUAN}

Anonim. 2008. Workshop Overview. Handbook \& Abstracts Catfish Aquaculture in Asia: Present Status and Challenges for Sustainable Development. Can Tho University, Vietnam. 5-7 Desember 2008, p. 5.
Dahuri, R. 2004. Industri Bioteknologi Perairan dan Kemakmuran Bangsa-Senin, 22 November 2004. Diunduh dari http://www2.kompas.com/kompas-cetak/ 0411/22/ilpeng/1389815.htm. Tanggal 3/31/2009 pukul 12.40 WIB.

Departemen Kelautan dan Perikanan. 2009. Produksi Perikanan Budidaya Menurut Jenis Ikan. Diunduh dari www.dkp.go.id. Tanggal 23/03/2009, pukul 10.30 WIB.

Hung, H.P., N.T.T. An, N.V. Trieu, D.T. Yen, V. Na-Nakorn, \& Thuy.T.T. Nguyen. 2008. Some technical and management aspect of catfish hatcheries in Hong Ngu District, Dong Thap Province. Aquaculture Asia Magazine. October-December, 2008, p. 23-25.

McManama, B.J. 2003. Past-Present-Future Catfish in Vietnam and the US. Aquaculture Magazine. May/June, $4 \mathrm{pp}$.

Monti, G., M. Crumlish, \& Ms T.T. Dung. 2009. The importance of pangasius farming in the Mekong Delta, Vietnam. Diunduh dari www.aqua.stir.ac.uk/AquaNews/ 32/p18-20.pdf. Tanggal 23/03/2009, pukul 10.40 WIB.

Phuong, N.T., Dang T. H. Oanh, \& N.A. Tuan. 2008. Striped Catfish (Pangasianodon hypophthalmus) Aquaculture in Viet Nam: An Unprecedented Development within a Decade. Handbook \& Abstracts Catfish Aquaculture in Asia: Present Status and Challenges for Sustainable Development. Can Tho University, Vietnam. 5-7 Desember 2008, p. 25.

Silva, D.S. 2008. Impediments to be Overcome in Attaining Success: An Inter-Governmental Agency View Point (p. 23). Handbook \& Abstracts Catfish Aquaculture in Asia: Present Status and Challenges for Sustainable Development. Can Tho University, Vietnam. 5-7 Desember 2008, p. 23.

Trong,T.Q., N.V. Hao, \& D. Griffiths. 2002. Status of Pangasiid aquaculture in Vietnam. MRC Technical Paper No. 2. ISSN: 1683-1489.

Wilder, M. \& N.T. Phuong. 2002. The status of Aquaculture in the Mekong Delta Region of Vietnam: Sustainable Production and Combined Farming System. Proceeding of International Commemorative Symposium: $70^{\text {th }}$ Anniversary of the Japanese Society of Fisheries Science. Fisheries Science Vol. 68, Suplemen I, November, 2002, 5 pp. 